\title{
Editor's Note: Contributions from the China-US Folklore and Intangible Cultural Heritage Project
}

\author{
Jason Baird Jackson
}

This issue of Museum Anthropology Review offers two papers originally presented at the Fifth Forum on China-US Folklore and Intangible Cultural Heritage held at the Museum of International Folk Art in Santa Fe, New Mexico, USA on November 10-11, 2014 (Figure 1). The theme of that fifth conference in a series was "Bridging Tangible and Intangible Cultural Heritage in Ethnographic Museums and Heritage Sites." I point here to some additional resources to help readers place these contributions into the context of the symposium at which they were presented and into the contexts of the larger projects and collaborations of which the Fifth Forum was a part. As a co-organizer of that Forum, I here record my appreciation for all who contributed to its success. I also thank Lijun Zhang and Gabrielle Berlinger for sharing their Forum contributions with the journal's readers. As always, the peer-reviewers who work behind the scenes evaluating and improving submissions to the journal are also deeply appreciated.

The full bilingual program and associated abstracts for the Fifth Forum are available on the website of the American Folklore Society. Along with programs from earlier and later Forum events, the program is presented there on a page that provides an overview of the China-US Folklore and Intangible Cultural Heritage Project, an ongoing initiative of the American Folklore Society and the China Folklore Society that was initiated in 2007 (AFS 2018a, 2018b). Tim Lloyd, Executive Director of the American Folklore Society, has also authored an account of the larger project on the occasion of its ten-year anniversary (Lloyd 2017a, 2017b).

The larger China-US Folklore and Intangible Cultural Heritage Project has, over the course of its history, included a number of sub-projects. The Fifth Forum (and the sixth as well) grew out of a museum-focused sub-project that was pursued between 2013 and 2016. That sub-project linked three Chinese museums of ethnography to three peer museums in the United States. The Mathers Museum of World Cultures, which I direct and which publishes Museum Anthropology Review, is one of those partnering museums. The sub-project pursued between 2013 and 2016 resulted in the co-produced exhibition and catalogue Quilts of Southwest China (MacDowell and Zhang 2016), two Forum events, professional staff exchanges between the participating museums, enriching travel to local communities in the home regions of the participating museums, and a range of spin-off events, exhibitions and new relationships. It is my hope that a full accounting of this project can be shared in a future issue of Museum Anthropology Review (see also Dewhurst 2017; Du 2017; Indiana University 2013; MacDowell 2017; MacDowell and Zhang 2016; Zhang 2017).

The project pursued during 2013-2016 led to a new phase of activity for the period 2017-2019. The focus of this new work is jointly pursued ethnographic work in China's Guangxi Zhuang

\footnotetext{
* This editorially reviewed contribution was accepted for publication in Museum Anthropology Review on January 16, 2017. The work is licensed under the Creative Commons Attribution 4.0 International License. To view a copy of this license, visit http://creativecommons.org/licenses/by/4.0/
} 
Autonomous Region. The Anthropological Museum of Guangxi is the lead institution for this new project, which includes the three U.S. partners as well as two community eco-museums with which the Anthropological Museum of Guangxi collaborates. The breadth of this effort is also beyond the scope of this editorial note. I mention it here to help situate the two peer-reviewed papers presented in this issue in their larger international collaborative context. Building on the start made in this issue, I anticipate that future issues of Museum Anthropology Review will feature scholarly articles and project reports derived from the China-US Folklore and Intangible Cultural Heritage Project since 2013 and carrying forward to 2019 and beyond.

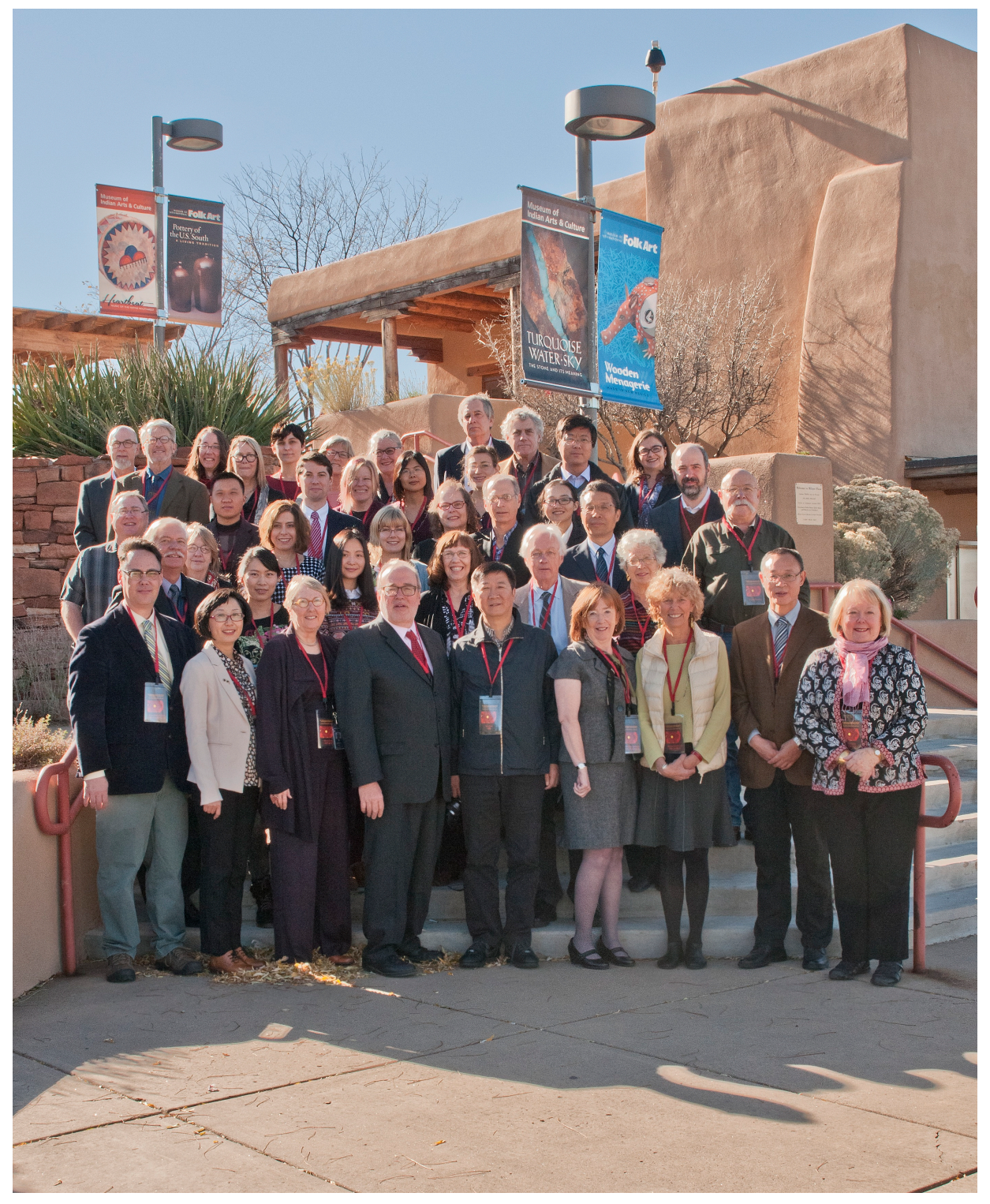

Figure 1. Participants in the Fifth Forum on China-US Folklore and Intangible Cultural Heritage held at the Museum of International Folk Art in Santa Fe, New Mexico, USA on November 1011, 2014. Photograph courtesy of the American Folklore Society. 
Turning from one kind of context to another, it is worth noting that the two papers share much more than a history of being presented at a particular scholarly gathering. Both also illustrate the contributions that vernacular architecture study can make to the study of ethnology, museum anthropology, museum-based folklore studies, and interdisciplinary heritage studies.

\section{References Cited}

American Folklore Society. 2018a. "China-US Folklore and Intangible Cultural Heritage." Accessed January 16, 2018. http://www.afsnet.org/?page=FICH

- 2018. "“China-US Folklore and Intangible Cultural Heritage.” Accessed January 16, 2018. https://web.archive.org/web/20171018200131/http://www.afsnet.org/?page=FICH

Dewhurst, C. Kurt. 2017. "Building Connectivity: China-US Folklife Collaborations.” In Metafolklore: Stories of Sino-US Folkloristic Communication, edited by Juwen Zhang and Junhua Song, 189-98. Guangzhou: Sun Yat-sen University Press.

Du, Yunhong. 2017. "Ten Years: China-US Museum Collaborations in Retrospect." In Metafolklore: Stories of Sino-US Folkloristic Communication, edited by Juwen Zhang and Junhua Song, 214-18. Guangzhou: Sun Yat-sen University Press.

Indiana University. 2013. "IU's Mathers Museum One of Three U.S. Institutions to Collaborate with Chinese Museums.” Accessed January 16. 2018.

http://archive.news.indiana.edu/releases/iu/2013/11/mathers-museum-collaboration.shtml

Lloyd, Tim. 2017a. "The Inside Story of the AFS China-US Project." AFS Review, June 12, 2017. http://www.afsnet.org/news/349609/The-Inside-Story-of-the-AFS-China-USProject.htm

- 2017b. "The Inside Story of the AFS China-US Project." AFS Review, June 12, 2017. https://web.archive.org/web/20171018213229/http://www.afsnet.org/news/349609/TheInside-Story-of-the-AFS-China-US-Project.htm

MacDowell, Marsha. 2017. "Reflections on Collaborations: The Quilts of Southwest China Project.” In Metafolklore: Stories of Sino-US Folkloristic Communication, edited by Juwen Zhang and Junhua Song, 199-207. Guangzhou: Sun Yat-sen University Press. and Lijun Zhang, eds. The Quilts of Southwest China. Nanning: Guangxi Museum of Nationalities and Bloomington: Indiana University Press.

Xie, Mohua. 2017. "My Two Stories.” In Metafolklore: Stories of Sino-US Folkloristic Communication, edited by Juwen Zhang and Junhua Song, 208-13. Guangzhou: Sun Yatsen University Press. 
Zhang, Lijun. 2017. "My Involvement in the Museum Exchange Projects." In Metafolklore: Stories of Sino-US Folkloristic Communication, edited by Juwen Zhang and Junhua Song, 221-27. Guangzhou: Sun Yat-sen University Press.

Jason Baird Jackson is the Editor of Museum Anthropology Review and the Director of the Mathers Museum of World Cultures at Indiana University, where he is also a Professor of Folklore Studies and Anthropology.

https://doi.org/10.14434/mar.v12i1.24353 